\title{
A Model to Evaluate 100-year Energy- mix Scenarios to Facilitate Deep Carbonization in the Southeastern United States
}



Approved for public release.

M. A. Adkisson

Distribution is unlimited.

A. L. Qualls

August 2016 


\title{
DOCUMENT AVAILABILITY
}

Reports produced after January 1, 1996, are generally available free via US Department of Energy (DOE) SciTech Connect.

Website http://www.osti.gov/scitech/

Reports produced before January 1, 1996, may be purchased by members of the public from the following source:

\author{
National Technical Information Service \\ 5285 Port Royal Road \\ Springfield, VA 22161 \\ Telephone 703-605-6000 (1-800-553-6847) \\ TDD 703-487-4639 \\ Fax 703-605-6900 \\ E-mail info@ntis.gov \\ Website http://www.ntis.gov/help/ordermethods.aspx
}

Reports are available to DOE employees, DOE contractors, Energy Technology Data Exchange representatives, and International Nuclear Information System representatives from the following source:

Office of Scientific and Technical Information

PO Box 62

Oak Ridge, TN 37831

Telephone 865-576-8401

Fax 865-576-5728

E-mail reports@osti.gov

Website http://www.osti.gov/contact.html

This report was prepared as an account of work sponsored by an agency of the United States Government. Neither the United States Government nor any agency thereof, nor any of their employees, makes any warranty, express or implied, or assumes any legal liability or responsibility for the accuracy, completeness, or usefulness of any information, apparatus, product, or process disclosed, or represents that its use would not infringe privately owned rights. Reference herein to any specific commercial product, process, or service by trade name, trademark, manufacturer, or otherwise, does not necessarily constitute or imply its endorsement, recommendation, or favoring by the United States Government or any agency thereof. The views and opinions of authors expressed herein do not necessarily state or reflect those of the United States Government or any agency thereof. 
Reactor and Nuclear Systems Division

Community College Internship Program

\title{
A MODEL TO EVALUATE 100-YEAR ENERGY-MIX SCENARIOS TO FACILITATE DEEP DECARBONIZATION IN THE SOUTHEASTERN UNITED STATES
}

\author{
M. A. Adkisson \\ A. L. Qualls
}

Date Published: August 2016

\author{
Prepared by \\ OAK RIDGE NATIONAL LABORATORY \\ Oak Ridge, TN 37831-6283 \\ managed by \\ UT-BATTELLE, LLC \\ for the \\ US DEPARTMENT OF ENERGY \\ under contract DE-AC05-00OR22725
}





\section{CONTENTS}

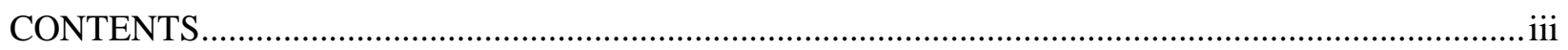

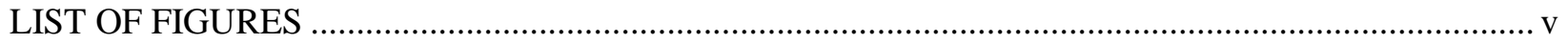

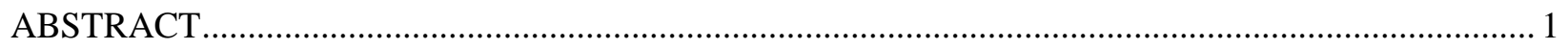

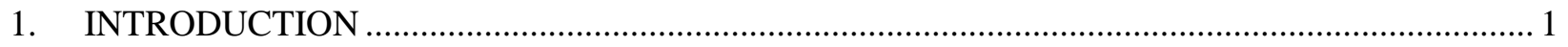

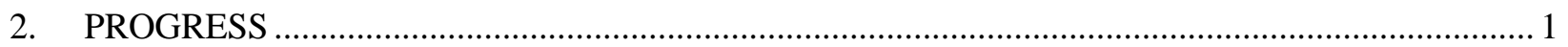

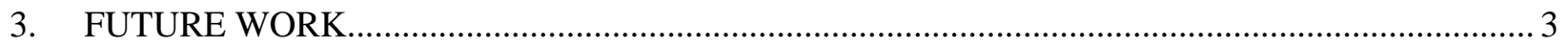

4. IMPACT ON LABORATORY OR NATIONAL MISSIONS ..............................................4

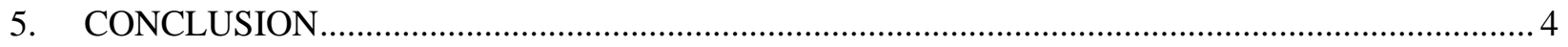

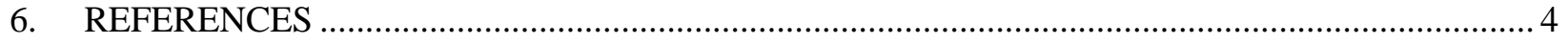





\section{LIST OF FIGURES}

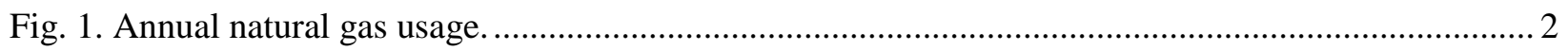

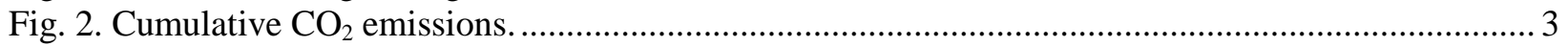

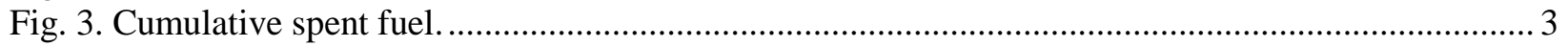





\begin{abstract}
The Southeast United States consumes approximately one billion megawatt-hours of electricity annually; roughly two-thirds from carbon dioxide $\left(\mathrm{CO}_{2}\right)$ emitting sources. The balance is produced by non- $\mathrm{CO}_{2}$ emitting sources: nuclear power, hydroelectric power, and other renewables. Approximately $40 \%$ of the total $\mathrm{CO}_{2}$ emissions come from the electric grid. The $\mathrm{CO}_{2}$ emitting sources, coal, natural gas, and petroleum, produce approximately 372 million metric tons of $\mathrm{CO}_{2}$ annually. The rest is divided between the transportation sector (36\%), the industrial sector (20\%), the residential sector (3\%), and the commercial sector (2\%). An Energy Mix Modeling Analysis (EMMA) tool was developed to evaluate 100 -year energy mix strategies to reduce $\mathrm{CO}_{2}$ emissions in the southeast. Current energy sector data was gathered and used to establish a 2016 reference baseline. The spreadsheet-based calculation runs 100year scenarios based on current nuclear plant expiration dates, assumed electrical demand changes from the grid, assumed renewable power increases and efficiency gains, and assumed rates of reducing coal generation and deployment of new nuclear reactors. Within the model, natural gas electrical generation is calculated to meet any demand not met by other sources. Thus, natural gas is viewed as a transitional energy source that produces less $\mathrm{CO}_{2}$ than coal until non- $\mathrm{CO}_{2}$ emitting sources can be brought online. The annual production of $\mathrm{CO}_{2}$ and spent nuclear fuel and the natural gas consumed are calculated and summed. A progression of eight preliminary scenarios show that nuclear power can substantially reduce or eliminate demand for natural gas within 100 years if it is added at a rate of only $1000 \mathrm{MWe}$ per year. Any increases in renewable energy or efficiency gains can offset the need for nuclear power. However, using nuclear power to reduce $\mathrm{CO}_{2}$ will result in significantly more spent fuel. More efficient advanced reactors can only marginally reduce the amount of spent fuel generated in the next 100 years if they are assumed to be available beginning around 2040. Thus closing the nuclear fuel cycle to reduce nuclear spent fuel inventories should be considered. Future work includes the incorporation of economic features into the model and the extension of the evaluation to the industrial sector. It will also be necessary to identify suitable sites for additional reactors.
\end{abstract}

\title{
1. INTRODUCTION
}

Deep decarbonization is the significant reduction of carbon dioxide emissions. Researchers are studying ways that carbon dioxide $\left(\mathrm{CO}_{2}\right)$ emissions affect people and the planet. As a result, the Deep Decarbonization Pathways Project [1], as well as others, are studying why $\mathrm{CO}_{2}$ emissions should be reduced and what steps need to be taken to reach the goal of total $\mathrm{CO}_{2}$ reduction. The Oak Ridge National Laboratory (ORNL) Energy Mix Modeling Analysis (EMMA) tool does not study $\mathrm{CO}_{2}$ impact. Rather, it evaluates strategies to achieve reduction goals. The project goals are to better understand the ways that various energy sources roles can realistically work to provide clean, reliable, affordable electricity to the Southeast United States. Non- $\mathrm{CO}_{2}$ emitting sources need to increase to produce a significant difference in emissions while maintaining demand. Making the switch from the current resources to new, cleaner sources is possible, but does not come without costs and the additional production of spent fuel.

\section{PROGRESS}

The states included in the model are Alabama, Florida, Georgia, Louisiana, Mississippi, North Carolina, South Carolina, and Tennessee. Energy sector data for the region was collected to populate a 2016 reference baseline. $\mathrm{CO}_{2}$ emissions by source, electricity in megawatts (electric) from different sources, emissions by sector, and electricity consumption by sector were (MWe) gathered. The model was built in Microsoft Excel $®$ to track demand and generation for 100 years based on assumptions about the market. 
A progression of eight scenarios was initially investigated. Scenario 1 projected what the electric sector would look like in 100 years if demand stayed constant and current nuclear power expired according to its current license expiration date and was replaced by natural gas generation. Scenario 1 was the baseline for following scenarios in which one variable was changed at a time. Scenario 2 accounts for an increased demand due to the passenger vehicle portion of the transportation sector moving to the electric grid. In Scenario 3, coal is removed completely over 100 years and natural gas consumption increases to meet that additional demand. Renewables are assumed to increase from their current levels to roughly $7 \%$ of total power in Scenario 4, which reduces the need for natural gas. No new nuclear power is added for Scenarios 1-4. Scenario 5 adds 1000 MWe per year to the grid from Light Water Reactors, significantly reducing the demand for natural gas. The same amount of nuclear power is added in Scenario 6 as in Scenario 5, but in Scenario 6 the reactors are assumed to be advanced reactors beginning in the year 2040. Advanced reactors have an assumed higher efficiency and therefore produce less spent fuel per MWe produced. In Scenario 7, a $20 \%$ increase in demand is assumed; 10\% from population growth and 10\% from economy growth. Scenario 8 shows a $20 \%$ demand decrease from assumed efficiency gains.

Comparison of the results from the eight scenarios showed three main points. The first major result was that if a transition to a lower-emission electricity sector were to occur, natural gas would be the source to meet demand in the near term. Natural gas emits approximately half of the $\mathrm{CO}_{2}$ that coal emits per unit of electricity produced. Thus, natural gas as a source of clean power is a better choice than coal. For the scenarios involving no new nuclear power natural gas generation replaces demand left as 1) existing nuclear plants go offline, 2) demand grows, and 3) coal generation goes offline. However, as shown in Figure 1, in scenarios in which new nuclear power is added, natural gas demand decreases and $\mathrm{CO}_{2}$ emissions can be eliminated from the electric sector.

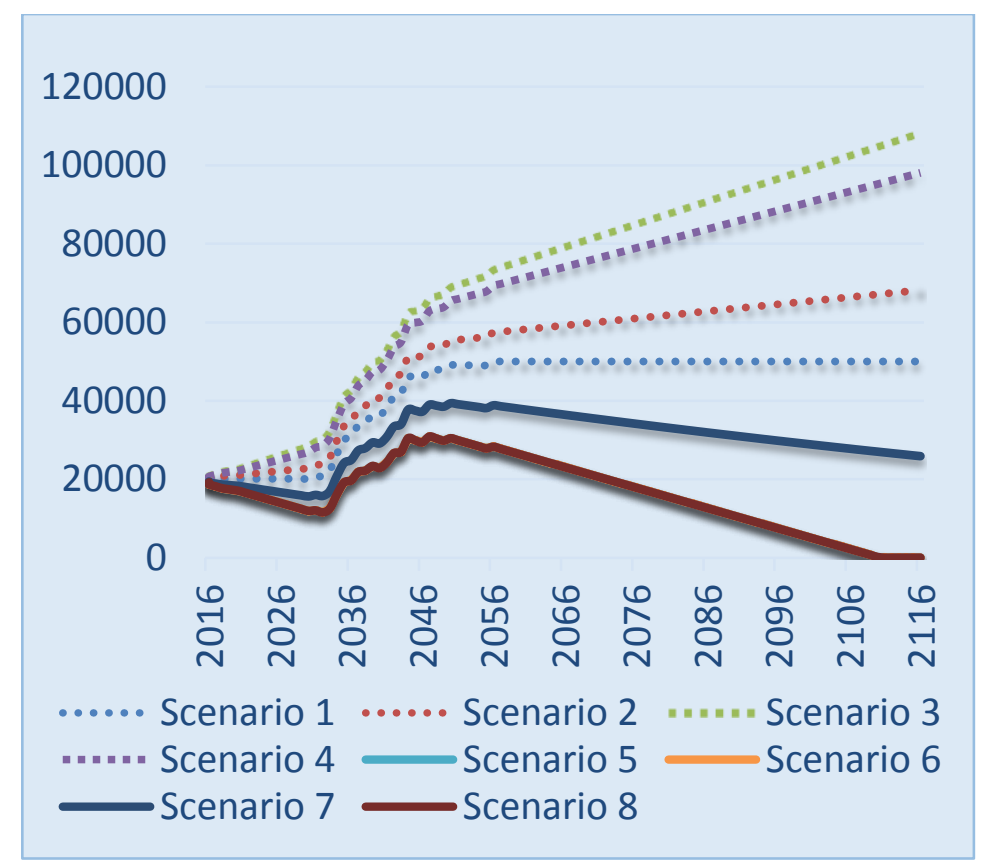

Fig. 1. Annual natural gas usage.

The second result relates closely to the first. Fig. 2 shows that for the first four scenarios there is modest reduction in the total $\mathrm{CO}_{2}$ emitted over 100 years. When new nuclear power is added in Scenarios 5-8 the annual $\mathrm{CO}_{2}$ emissions significantly decrease and under some circumstances can be reduced to zero. 


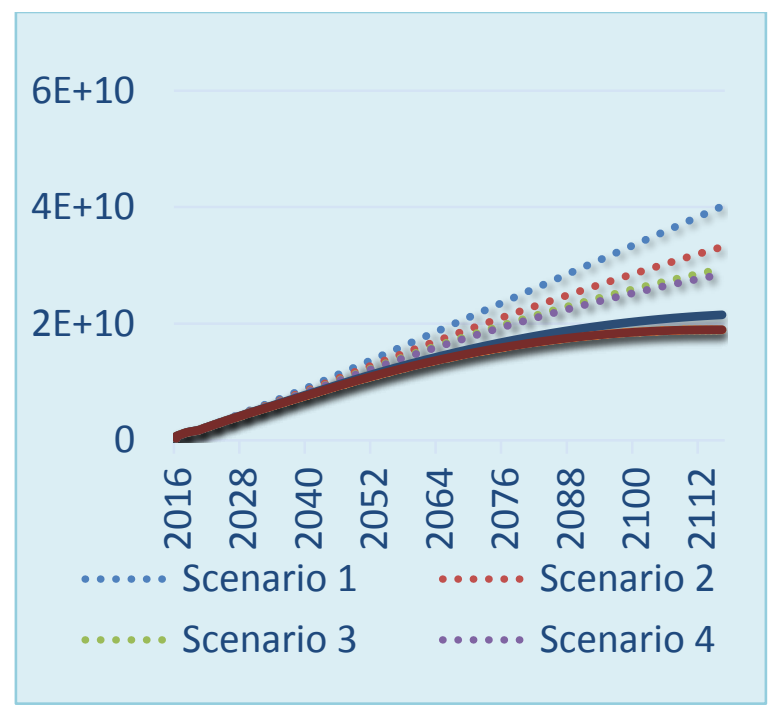

Fig. 2. Cumulative $\mathrm{CO}_{2}$ emissions.

Scenarios 1-4 produced the same amount of nuclear spent fuel because no new nuclear power is added. As shown in Figure 3, when new nuclear power is added, spent fuel production increases. The amount of spent fuel produced by light-water reactors is only slightly more than the amount produced by advanced reactors in Scenario 6 for the projected 100 years. The difference between the two values will increase with time. However, closing the fuel cycle should be a priority in either case.

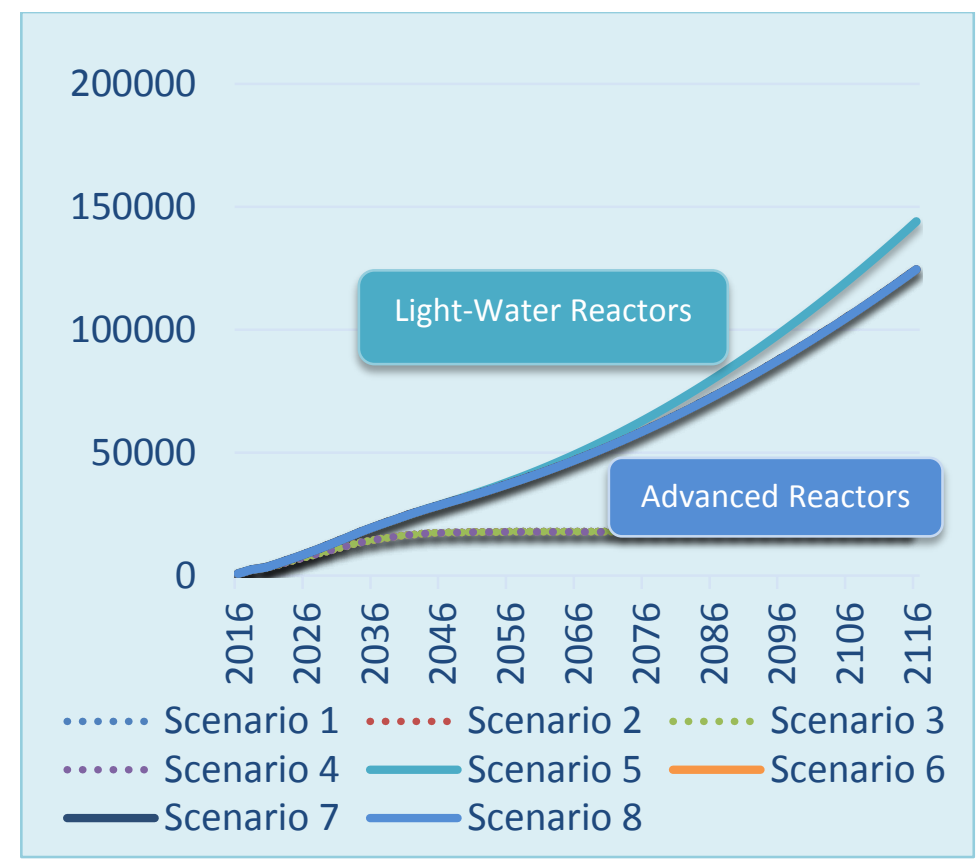

Fig. 3. Cumulative spent fuel.

\section{FUTURE WORK}

Economic variables should be considered in the scenarios and can be easily added to the analysis by accounting for capital costs, fuel costs, carbon taxes, and disposal costs. Also, the scenarios in this model address only the electric grid sector and a portion of the transportation sector. The largest remaining $\mathrm{CO}_{2}$ 
emitting sector is the industrial sector. This same methodology could be extended to analyze the industrial, commercial, and residential sectors. Constraints that might limit the ability to execute scenarios should also be considered. These include the ability to site the number of reactors needed and the rate at which they should come online.

\section{IMPACT ON LABORATORY OR NATIONAL MISSIONS}

This project relates to the discussion of a rational transition away from fossil fuels. It will take time and investment to change the energy sector. ORNL is directly involved with climate change research and national energy infrastructure development. The Reactor and Nuclear Systems Division leads projects focusing on the development of advanced reactors and closing the nuclear fuel cycle.

This project was funded by The Community College Internship program within the Department of Energy.

\section{CONCLUSION}

A model to study the Southeastern United States' electricity sector was developed and scenarios were run to demonstrate potential strategies to significantly reduce $\mathrm{CO}_{2}$ emissions. From the eight scenarios studied three major results were found. First, increased natural gas usage is likely in the near term, but is impacted by demand changes and the availability of other sources. In scenarios where nuclear power is introduced, natural gas usage decreases and there is a potential to completely eliminate $\mathrm{CO}_{2}$ emissions from the electrical sector by removing coal and natural gas from the grid. The third result is that as more nuclear power is added to the grid more spent fuel is accumulated and needs to be managed.

\section{REFERENCES}

1. Deep Decarbonization Pathways Project (2015). Pathways to deep decarbonization 2015 report-executive summary, Sustainable Development Solutions Network - Institute for Sustainable Development and International Relations. 